\title{
Functional Architecture of the Human Superior Mesenteric Vein
}

\author{
By
}

\begin{abstract}
José Ricardo Barros Pernambuco, Claudio a. Ferraz de Carvalho, Romeu Rodrigues de SOUZA and Aldo Junqueira Rodrigues Jr.
\end{abstract}

\author{
Department of Anatomy, São Paulo University, São Paulo, Brasil \\ -Received for Publication, November 29, 1982-
}

Key Words: Mesenteric vein, Functional architecture.

\begin{abstract}
Summary: The muscular, collagen and elastic fiber dispositions of the superior mesenteric vein wall were studied in 40 antaomic specimens by various mesoscopic and microscopic techniques.

The muscular fibers follow a crossed spiral pattern. Close to the superior mesenteric vein junction with the portal vein, these spirals are elongated and they become progressively flattened towards the ileocecal region where they tend to a circular disposition. At the tributary vein entrance, circular bundles of the intima layer of the superior mesenteric vein bend towards its ostium thus forming annular thickenings. The collagen fibers form pantographic networks in the superior mesenteric vein wall, crossing each other at different angles in the three layers of the vessel. The elastic fibers follow the same disposition as the muscular fibers.

Morphofunctional considerations are discussed.
\end{abstract}

\section{Introduction}

The microscopic anatomy of the superior mesenteric vein has been little studied and usually from a strictly histologic viewpoint (Andreassi 1932; Dubreuil 1932; Sousa 1932; Del Dentici 1936; Li 1940; Brendle 1950 ; Kügelgen 1951 ; and Ishida 1960).

In this study, an integrated analysis of the muscular, elastic and collagen fiber dispositions was carried out in the superior mesenteric vein wall from the ileocolic vein up to its opening in the portal vein, employing mesoscopic and microscopic techniques.

\section{Materials and Methods}

Forty anatomic specimens including melanodermal and leukodermal individuals of both sexes, aged from 18 to 80 years, were studied. The pieces were removed as blocks during necropsy.

In six pieces, $10 \mu \mathrm{m}$ paraffin sections were stained by Masson's trichromic method (Romeis 1948) for elastic and muscular fibers and by the Weigert and Verhöff methods (1908) for elastic fibers. Unstained sections were studied under polarized light.

Sixteen pieces were embedded in celloidin and cut into $100 \mu \mathrm{m}$ sections, stained with Azan, according to the method of Heidenhain (Roneis 1948) and 
Weigert, as modified by Debelow (1950 and 1951) and Ferraz de Carvalho (1970). Unstained sections were examined under polarized light with a Rot II quartz filter using a stereomicroscope $(6 \times$ to $40 \times)$.

One specimen, submitted to frozen sectioning was stained with Sudan III (Romeis, 1948) and Weigert for elastic fibers.

Thirteen pieces were studied as stretch preparations: one was stained by the Van Gieson method according to Otto (1963); six were prepared by the Semper method, according to Voss (1939) for collagen and muscular fibers; three were treated by the Marcacci method according to Parolari (1952) for muscular fibers, and two of these were also stained with Azocarmine according to Ferraz de Carvalho (1970); another specimen was submitted to the Scott method (1950) modified by Motti (1958) also for muscular fibers; and the two last were prepared by the Sauser method (1931) to differentiate the adipose tissue. This group of specimens was examined under the stereomicroscope.

The last four pieces were reduced to three thin layers each, stained by the Weigert and Azan methods (according to Ferraz de Carvalho 1978) and examined under polarized light using the stereomicroscope.

\section{Results}

The muscular fibers follow a coiled crossed bundle pattern. The muscular bundles are continuous from the surface to depth but present variations of inclination resulting in an apparent stratification (Fig. 1). Longitudinally disposed fibers predominate in the tunica adventitia, oblique ones in the media and circular ones in the intima (Figs. 2, 3 and 4). The fibers are disposed from the surface to depth, either downwards or upwards and from right to left or from left to right so that there is no polar orientation of the muscular bundles.

The coiled elongated trajects of the muscular fibers close to the entrance of the superior mesenteric vein on the portal vein become progressively flattened towads the ileocecal region where they tend to a circular disposition. At the level of the entrance of the tributary veins, muscular circular bundles of the superior mesenteric vein intima bend towards the respective entries where they form annular thickenings mainly at the expense of the intima but also of the vein media (Figs. 5,6 and 7). Longitudinal muscular fibers of the superior mesenteric vein adventitia incline towards the tributary vessels, surpass the ring-shaped thickening but do not have any continuity relationship with it.

The collagen fibers of the superior mesenteric vein wall are disposed according to a pantographic network pattern. They cross each other at approximately right angles at the adventitia, while at the media they become more acute in relation to the long axis of the vessel and at the intima they tend to become at right angles but forming a much denser network of thinner fibers (Figs. 8 and 9).

It seems that there are more collagen fibers on the ventral than on the dorsal aspect of the superior mesenteric vein.

The elastic fibers appear to have approximately the same orientation as the muscular ones and also participate in the annular thickenings at the tributary vein entries. Except in the tunica intima, where they become circular, the elastic fibers follow a longitudinal disposition (Fig. 10). Mioelastic bundles are rarely observed and are present at the adventitia only in the distal third of the superior mesenteric vein (Fig. 11).

A voluminous adipose pat encloses the superior mesenteric vein (Fig. 12). It is 
related to the peritoneum and subperitoneal structures by means of a conjunctive framework of thin and delicate fibro-elastic bundles. It seems that more adipose tissue exists ventrally than dorsally to the superior mesenterie vein.

\section{Discussion}

A few authors have studied the spatial architecture of the superior mesenteric vein muscular-conjunctive system. Muscular helicoidal trajects were described by Kügelgen (1951 and 1956) for the veins in general and, more specifically, for the veins of the portal system by Ferraz de Carvalho (1966 and 1970) and Prado Reis (1976). Bunce (1958) observed a helicoidal spiral arrangement of muscular fibers for the veins in general but only at the media; in the superior mesenteric vein, this disposition is seen in the adventitia as well. The model proposed by Prado Reis (1976) for the splenic vein with two layers of muscular fibers, one superficial and the other profound, integrated in only one double crossed spiral system, can also be applied to the superior mesenteric vein but, in the latter, the stratigraphic disposition is not so evident.

A longitudinal muscular fiber arrangement at the adventitia has also been described in the portal vein by Ferraz de Carvalho (1978). In this vein, however, mioelastic bundles are abundant, whereas they are rarely found in the superior mesenteric vein.

The collagen fiber disposition in an elongated mesh network in the superior mesenteric vein appears to resemble that of the splenic vein (Prado Reis, 1976). The greater density of collagen fibers on the ventral aspect of the superior mesenteric vein as compared to its dorsal aspect could depend on extrinsic factors as postulated by Petersen (1935) and Benninghoff (1930) for other vessels.
Bucciante (1938 and 1943) noted that the coronary artery shows a thinner wall when in contact with the miocardium.

In the superior mesenteric vein, the angles of intersection the collagen fibers diminish from the adventitia towards the media but enlarge again at the intima layer. This arrangement is similar to that described by Ferraz de Carvalho (1978) for the portal vein as well as for the hollow viscera in general (Ferraz de Carvalho 1973). This arrangement could, according to this author, be related to the tubular organ wall resistance to the intraluminal pressure.

The elastic membranes described for the veins in general by Andreassi (1932), Del Dentici (1936) and Li (1940) were not observed in the superior mesenteric vein. We confirmed, however, the findings of Kügelgen (1951) concerning the disposition of the elastic fibers forming a continuous longitudinal network throughout the whole thickness of the vein wall.

Mioelastic bundles would act to amplify the vascular lumen (Dubreuil and Lacoste 1931 ; Scelkunov 1935; Benninghoff 1948; Kügelgen 1951 and 1956; Meyer and Kliebsch 1964; Prado Reis 1976; and Ferraz de Carvalho 1970 and 1978). Since they are rare in the superior mesenteric vein, it can be considered that they play a secondary role in dilating this vein.

The superior mesenteric vein presents limited connections with the neighboring tissues and is immersed in a voluminous and plastic adipose pat. It can be accepted "a priori" therefore that the "fixed point" of the muscular bundles (described by Goertler 1951) is localized in the middle of the bundles themselves

According to Goertler (1934 and 1951), when the angle of inclination of the muscular spirals of the vessel is greater than $45^{\circ}$, their contraction will initially yield a widening of the lumen with 
ascension and consequent flattening of the spirals. When that angle is less than $45^{\circ}$, so tending to give a circular disposition, the muscular contraction must determine the narrowing of the lumen through a kind of "sphincteric" mechanism with which the spirals elongate again. This must occur when the muscular tube has few connections with the surrounding structures as in the case of the superior mesenteric vein.

The musculature of the superior mesenteric vein presents, as already mentioned, inclinations of its spiral systems that diminish from the portal vein towards the bowel. On the other hand, under physiologic conditions, the blood flows in the opposite direction.

Such a disposition of the musculature appears to support the idea of blood propulsion: according to Goertler's theories, as the inferior muscular bundles contract they meet their "sphincteric" condition narrowing the lumen because their muscular spirals now already have a disposition close to the annular ordination. The spirals which are localized superiorly, as their angles of inclination become larger, reach this sphincteric component progressively upwards in subsequent steps during contraction. They would have, however, an intermediary dilation phase due to reduction of the inclination angles and flattening of its spirals. The constrictive sphincteric phase would begin when the spiral system reaches an inclination angle of $45^{\circ}$.

If we consider this sequency of events valid, we can accept such a morphofunctional idea of actual "blood propulsion" upwards. This hypothetical sequence resembles the pump function of the heart. The annular thickenings of the musculature at the entries of the superior mesenteric vein tributaries lead us to suppose their involvement in a controlling mechanism of venous return to their territories.

\section{References}

1) Andreassi, G.: La struttura della vena porta, delle sue radici e dei suoi rami terminali nell'uomo con speciale riguarda at tessuto muscolare liscio. Ric. Morfol., 12: 299-319, 1932.

2) Benninghoff, A.: Blutgefässe und Herz. In: Handbuch der Mikroskopischen Anatomie des Menschen. Hrsg. von W. von Möllendorff. Berlin, J. Springer, 1930. v. 6 pt. 1 p. 1-225.

3) Benninghoff, A.: Lehrbuch der Anatomie des Menschen. 3 Aufl. Berlin, Urban \& Schwarzenberg, 1948. v. 2, p. 2-148.

4) Brendle, D.: Über den Bau der Menschlichen Pfortader und ihrer Wurzeln. Acta. Anat. (Basel), $10: 108-129,1950$.

5) Bucciante, L.: Differenze di spessore nella parete di una determinata vena in dependenza del rapporto con organi contigui. Boll. Soc. ital. Biol. sper. 13: 990-992, 1938.

6) Bucciante, L.: Nuove acquisizioni sull' anatomia microscopica del sistema venoso. Med. Biol. 2: 35-65, 1943.

7) Bunce, D.F.M.: Comparison of architecture of arteries and veins in distented and constricted states. Anat. Rec., 130 : 279, 1958 (Abstract).

8) Dabelow, A.: Vorstudien zur Betrachtung der als funktionelles System. Verh. anat. Ges. (Jena), $97:$ 132-145, 1950.

9) Dabelow, R.: Vorstudien $z u$ einer Betrachtung der zunge als funktionelles System. Morph. jb. 91: 33-76, 1951.

10) Del Dentici, D.L.: Vene superficiali e vene profunde. Monit. Zool. ital., 47: 99-102, 1936.

11) Dubreuil, G.: Adaptation of structure of venous walls to local circulatory conditions. Ann. Fac. Franc. Med. Pharm. Beyrouth, 1: 74-93, 1932.

12) Dubreuil, G. \& Lacoste, A. : Histophysiologie des parois vasculaires arterielles et veineuses de l'homme. Ann. Anat. path., 8: 988-1041, 1931.

13) Ferraz de Carvalho, C. A.: Sur L'angioarchitecture veineuse de la zone de 
transition oesophago-gastrique et son interprétation fonctionnelle. Acta. Anat. (Basel), 64: 125-162, 1966.

14) Ferraz de Carvalho, C.A.: Studies on the microscopic anatomy of the veins in the esophagogastric transition zone in man. Rev. Hosp. Clin. Fac. Med. Univ. S. Paulo, 25: 289-302, 1970.

15) Ferraz de Carvalho, C.A.: Aspectos morfofuncionais de artérias de natureza muscular. Hospital (Rio de J.), 77 : 1863-1879, 1970.

16) Ferraz de Carvalho, C. A.: Contribution to the functional study of tubular viscera. Arq. Gastroenterol., 10: 183-190, 1973.

17) Ferraz de Carvalho, C.A.: Functional anatomy of the portal vein and its main and segmental branches in the adult man. Anat. Anz., 143: 50-71, 1978.

18) Goerttler, K.: Die Konstruktion der wand des menschlichen Samenleiters und ihre funktionelle Bedeutung. Morph, Jb., $74: 550-580,1934$.

19) Goerttler, K.: Die Bedetung der funktionellen struktur der gefasswand IUndersuchungen and der nabelschmurarterie des menschen. Morph. Jb., 91: 368-393, 1951.

20) Ishida, M.: The arrangement of the elastic fibres in the wall of human veins. Acta. Anat. Nippon., 35: 129-139, 1960.

21) Kügelgen, A.V.: Über den wandbau der grossen venen. Morph. Jb., 91: $447-482,1951$.

22) Kügelgen, A.V.: Weitere mitteilungen über den wandbau der grossen venen des menschen under besenderer berücksichfigung ihrer Kollagenstrukturen. Z. Zell. forsch., 44 : 121-174, 1956.

23) Li, Pei-Lin.: Adaptation in veins to increased intravenous pressure, with special reference to the portal system and inferior vena cava. J. Pathol. Bact., 50: 121-136, 1940.

24) Meyer, W.W. \& Kliebsch, N.: Über das
Vorkommen von elastischmuskulösen Systemen in den venen des menschen. $Z$. Zellforsch., 62 : 504-513, 1964.

25) Motti, V.J.: Tecnica para dissociaçåo da túnica muscular do tubo digestivo. Fol. clin. biol. (S. Paulo), 28 : 181-184, 1958/59.

26) Otto, W.: Ein beitrag zur konstruktionsanalyse des gallenblasenhalses und des ductus cysticus. Anat. Anz., 113: 357380, 1963.

27) Parolari, J.B.: Observaçoes sobre a arquitetura do chamado esfincter de ODDI no homem. Săo Paulo, 1952. (Tese de Livre docência. Fac. Med. USP).

28) Petersen, H.: 1935-apud: Kügelgen, A. V. (21).

29) Prado Reis, F.: Estudo morfof uncional da artéria e veia esplênica no homem adulto. São Paulo, 1976. (Tese de doutoramento. Inst. Ciências Biomédicas. USP).

30) Romeis, O.: Mikroskopische Technik. $15^{\circ}$ Aufl. München, Oldenbourg, 1948.

31) Sauser, G.: Fettfärgung makroskopischer Preparate mit Sudan. Anat. Anz., 72: 419-424, 1931.

32) Scelkunov, S.: Elastic and muscular elements in wall of veins of small caliber. Z. Anat. Entwckl.-Gesch., 105: 94-107, 1935.

33) Scott, P.P.: Use of hyaluronidase in microtechnique. Nature (Lond.), 166: 479, 1950.

34) Souza, O.M.: Quantitative histologic studies on smooth musculature. Bull. Histol. Physiol., 9: 196-208, 1932.

35) Verhoff, F.H.: Some new staining methods of wide applicability. Including a rapid differential stain for elastic tissue. J. Amer. med. Ass., $50: 876-877$, 1908.

36) Voss, H.: Makroskopisch Anatomische Praparationstecnnik. Leipzig. Akadem. Verlagsgesellschaft. 1939 p. 5-6. 


\section{Explanation of Figures}

\section{Plate I}

Fig. 1. Schematic model of the muscular fibers tridimensional architecture of the superior mesenteric vein wall.

Fig. 2. Oblique crossed muscular bundles at the superior mesenteric vein tunica media. Tangential section. Azan. $\times 800$.

Fig. 3. Circular muscular bundles at the superior mesenteric vein tunica intima. Tangential section. Azan. $\times 2000$.

Fig. 4. Muscular longitudinal and crossed bundles (arrows) at the superior mesenteric vein tunica adventitia. Tangential section. Azan. $\times 316$. 

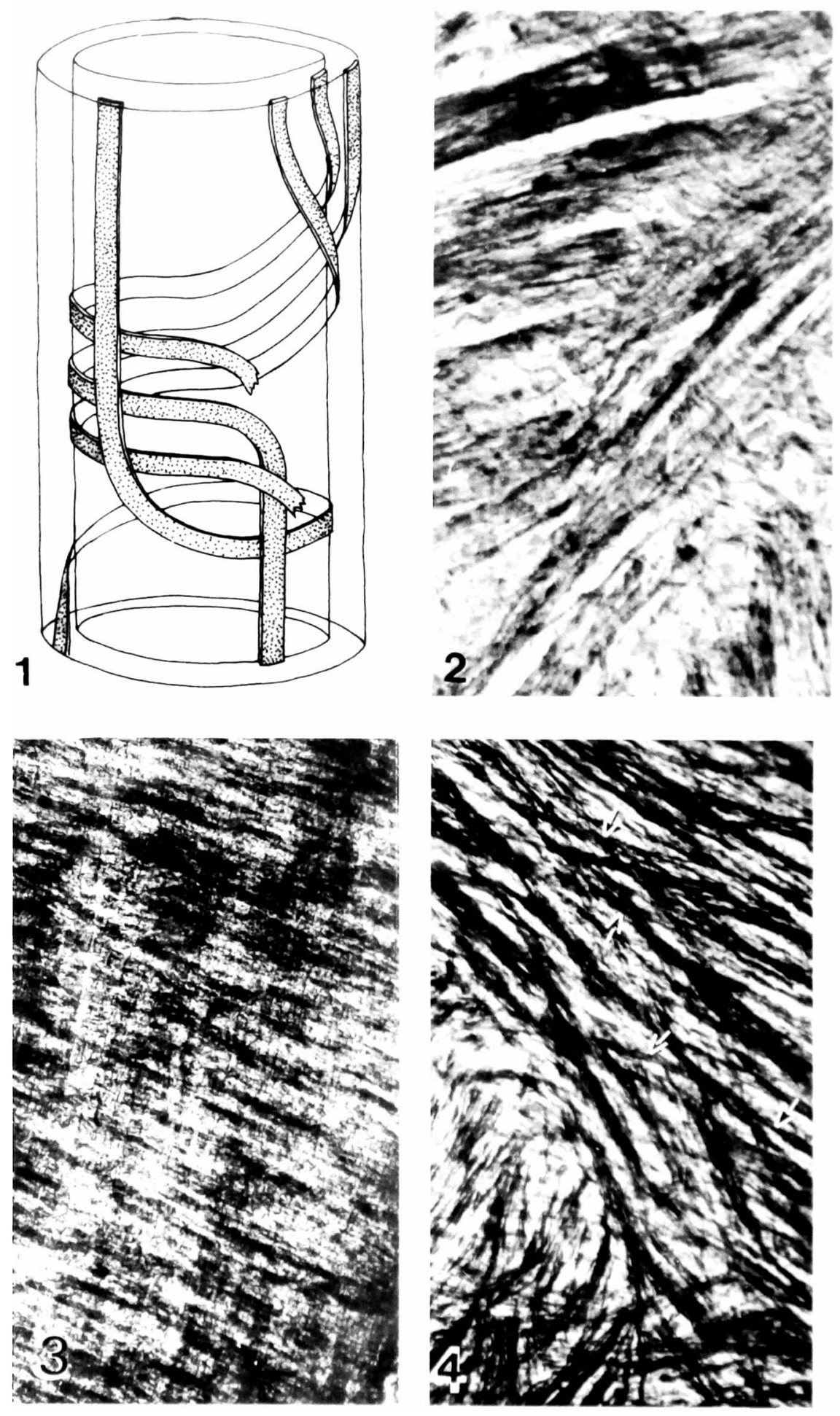


\section{Plate II}

Fig. 5. Schematic model of the muscular fiber disposition of the superior mesenteric vein, at the entrance of a tributary vein.

Fig. 6. Muscular circular bundles of the superior mesenteric vein intima (arrows) forming thickenings at the entrance of a tributary vein. Cross section. Masson. $\times 404$.

Fig. 7. Muscular circular bundles of the superior mesenteric vein intima (I) and media (M) at the entrance of a tributary vein. Cross section. Masson. $\times 800$.

Fig. 8. Collagen network at the superior mesenteric rein adventitia. Tangential section. Polarized light. $\times 800$. 

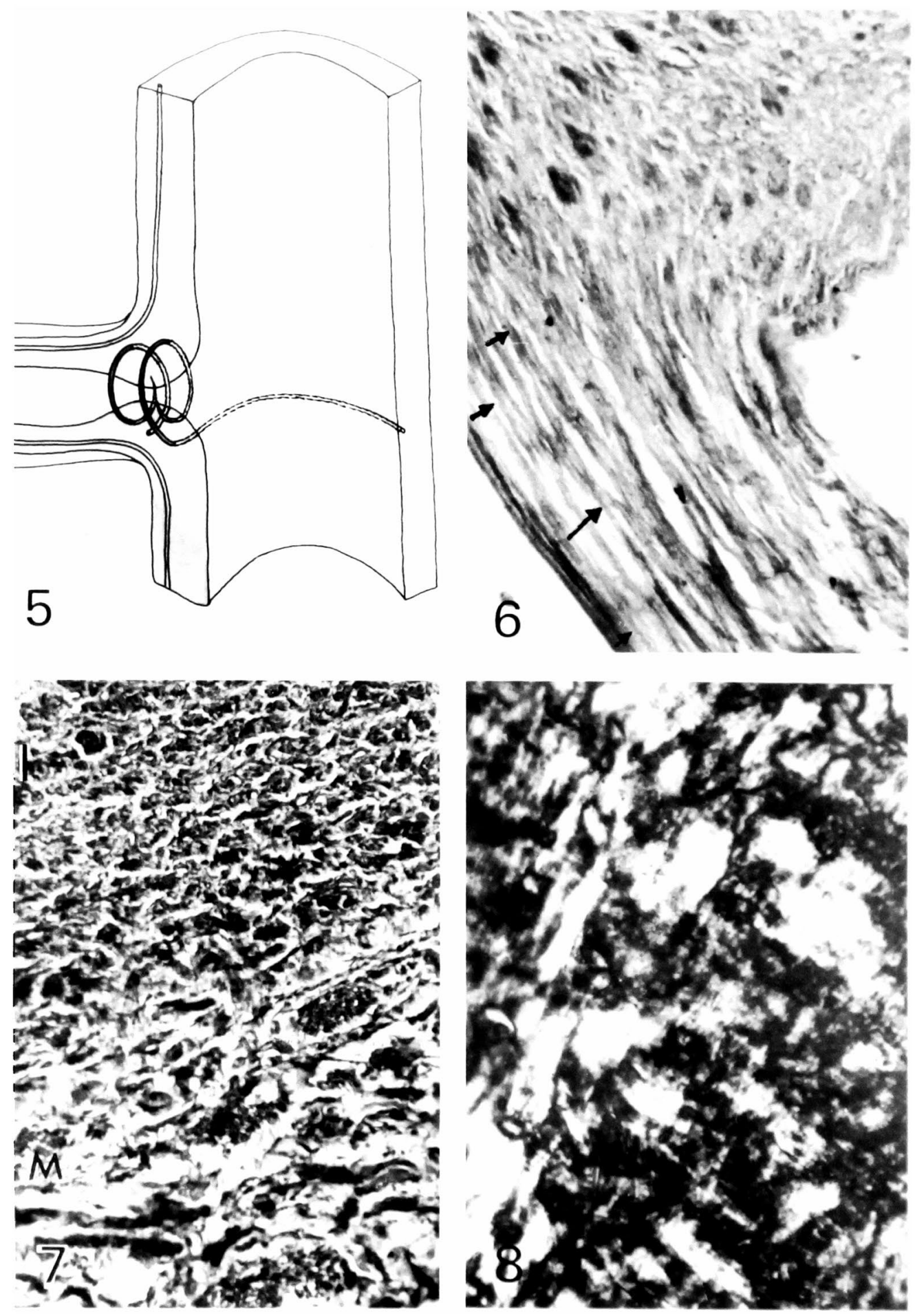


\section{Plate III}

Fig. 9. Collagen network at the superior mesenteric vein media (M) and intima (I). Tangential section. Polarized light. $\times 200$.

Fig. 10. Elastic longitudinal bundles at the superior mesenteric vein adventitia (A). Longitudinal section. Weigert. $\times 404$.

Fig. 11. Mioelastic bundle at the superior mesenteric vein adventitia. Longitudinal section. Weigert. $\times 800$.

Fig. 12. Adipose pat enclosing the superior mesenteric vessels. The peritoneum is seen at the right. Thick section $(0.5 \mathrm{~cm})$. Sauser method. $\times 14$. 

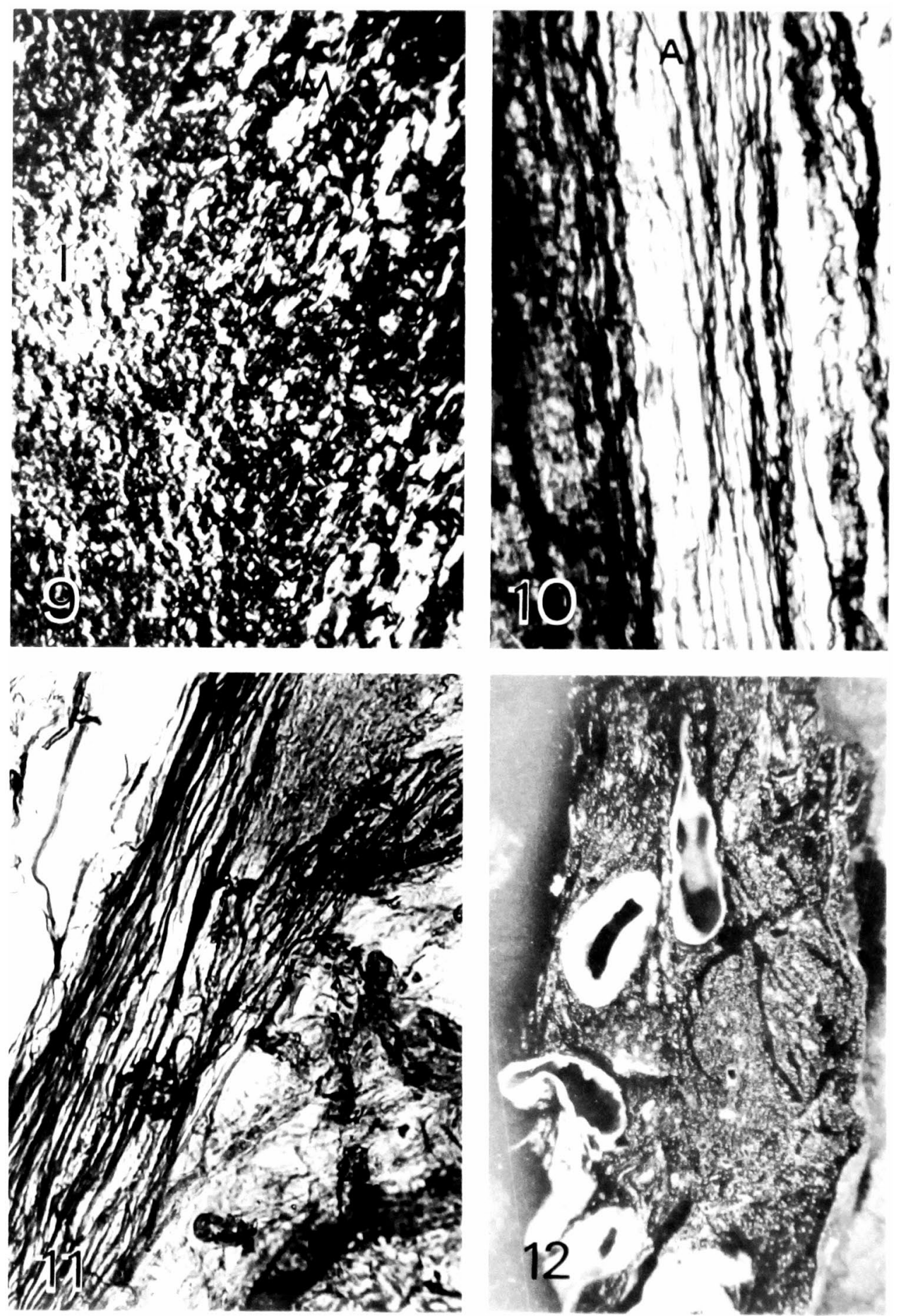